\title{
Medieval medical schools in the Seljuk and Ottoman empires
}

\author{
Mehmet Turgut
}

Published online: 13 January 2009

(C) Springer-Verlag 2008

Throughout the Middle Ages, two Turkish empires (Seljuks and Ottomans), placed between the East and West, influenced the surrounding world in a powerful way. It is accepted that they used Islamic medical doctrines derived basically from Greco-Roman scientists, such as Hippocrates and Galen, and Islamic scientists, such as Avicenna and AlZahrawi $[1,2]$. The Turkish (Anatolian) Seljuks attributed much importance to the sciences and they set up a specific building consisting of a "medrese" (medical schools) and a medical center, named "Darush-Shifa," "Dar al-Shifa," "Darul-Afiye," or "Darus-Sihna" in Anatolia dating back to 1217 in which experienced physicians trained medical students (Fig. 1) (http://www.kayseri.gov.tr/images/resim random/gevher_nesibe_tedavi.jpg). The most famous of these are the Gevher Nesibe in Kayseri (1205), the Izzettin I Keykavus in Sivas (1217), the Torumtay in Amasya (1266), the Pervaneoglu Ali in Kastamonu (1272), and the Muinuddin Pervane in Tokat (1275) (http://www.kayseri. gov.tr/images/resim_random/gevher_nesibe_tedavi.jpg).

In the Ottoman, the students were chosen from the brightest of "devşirme" children between 8 and 20 years of age who were conscripted from the non-Muslim populations of the Balkans before adolescence according to the system beginning with Murat I at 1363, and they were educated in the area of science, including medicine, and technology in the institution of Topkapi Palace, known as the Enderun (Fig. 2) (http://www.shareapic.net/324971HISTORY-OF-ANATOLIA.html; http://www.femir.org/

M. Turgut $(\square)$

Department of Neurosurgery, School of Medicine,

Adnan Menderes University,

09100 Aydın, Turkey

e-mail: drmturgut@yahoo.com

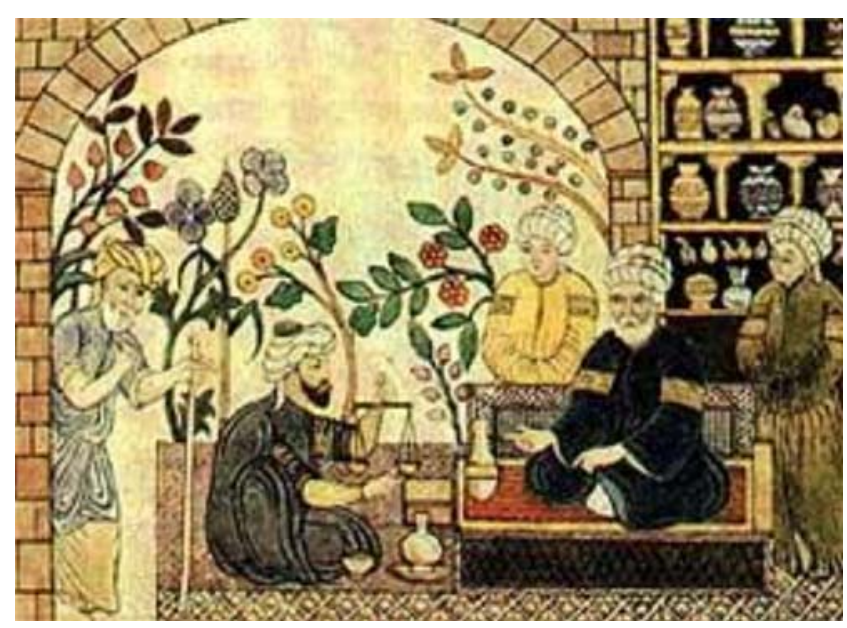

Fig. 1 A miniature illustrating the admission of a patient by experienced physician and his students for the treatment in the Gevher Nesibe Medical School. Reprinted with permission of Mr. Harun Evren from the Republic of Turkey Governor of Kayseri, Turkey (http://www. kayseri.gov.tr/images/resim_random/gevher_nesibe_tedavi.jpg)

osmanli-kultur-ve-uygarligi-osmanlilarda-egitim-ogretimbilim-ve-sanat.html) [3]. The drawing on the cover of Child's Nervous System depicts an adolescent boy from newly conquered Christian territories by the practice of "devșirme" for medical training (Fig. 3) (http://www. gezikitap.com/resimler/galeri/muk-2b.jpg). During the Ottoman Empire, the following medical centers were built in the following cities: Amasya Darüssifa in Amasya (1308), Yıldırım Darüssifa in Bursa (1399), Fâtih Darüssifa in İstanbul (1470), Leprocy Center and Mental Hospital in Edirne (1488), and Hafsa Sultan Darüssifa in Manisa (1522) [4]. In the premodern era, various medical and surgical treatment options were practiced for headache, 


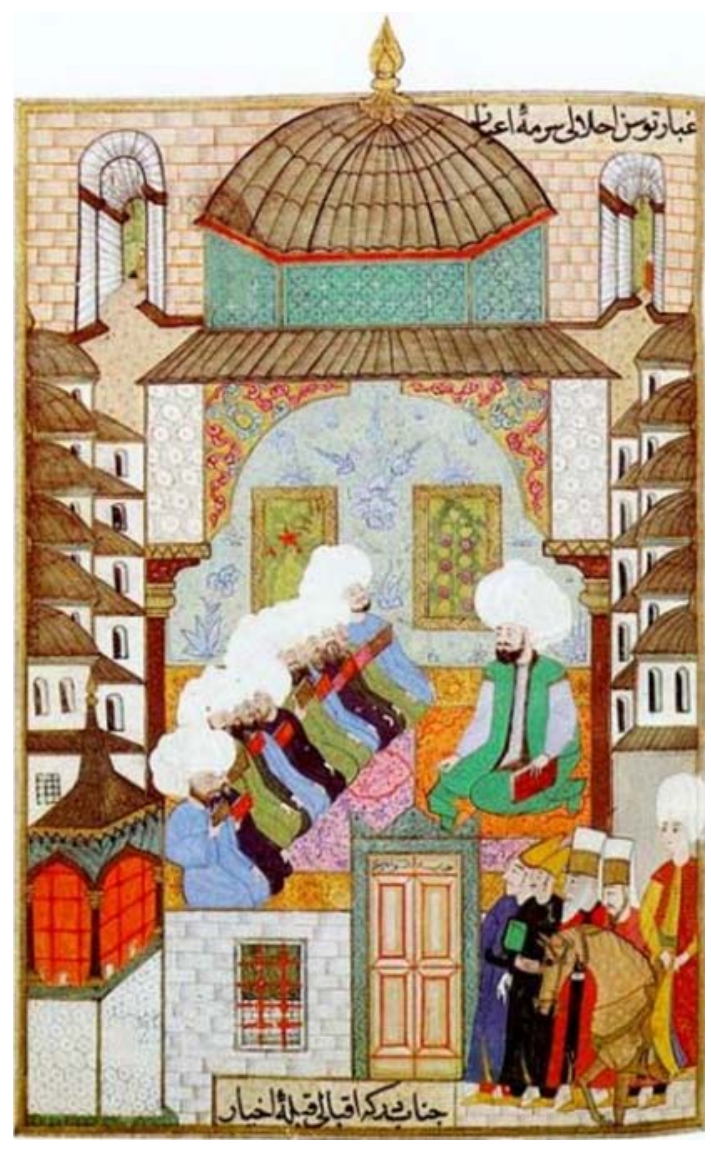

Fig. 2 A miniature illustrating a specific teacher and a large number of students of the Enderun in Topkapi Palace, İstanbul. Reprinted with permission of Mr. Firat Emir, historian, from his private collection (http:// www.femir.org/osmanli-kultur-ve-uygarligi-osmanlilarda-egitim-ogretimbilim-ve-sanat.html)

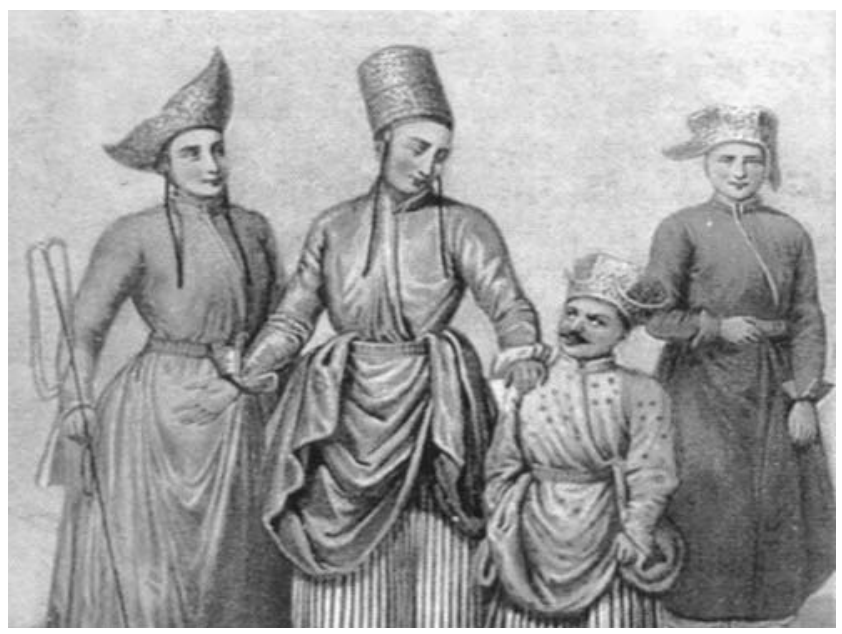

Fig. 3 The picture used on the cover illustrates a drawing depicting the Enderun students, including young boys taken from their families according to a system named "devşirme," one of them was the dwarf boy and the other was the "mute of Enderun" from Palace buffoons, as well as the internal masters. Reprinted with permission of Mr. Talha Uğurluel, historian, from his private collection (http://www.gezikitap. com/resimler/galeri/muk-2b.jpg)

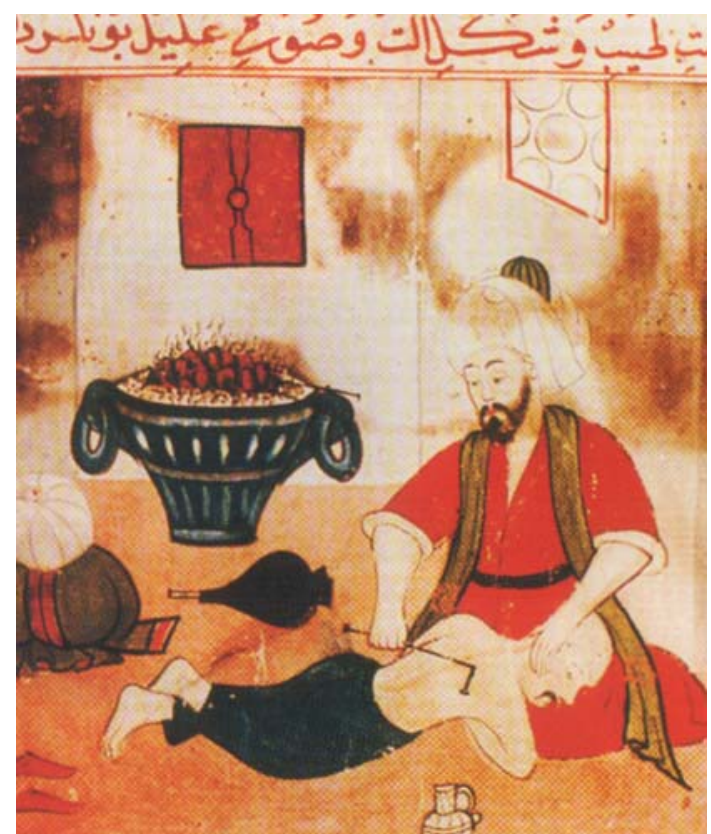

Fig. 4 A gravure demonstrating the treatment of a patient using cauterization technique by Şerefeddin Sabuncuoğlu in Amasya. Reprinted with permission of the Atatürk Institute of Culture, Language and History, Institute of Turkish History from Uzel I [1]

low back pain, epilepsy, hydrocephalus, and vertebral fracture and dislocations by some physicians including Şerefeddin Sabuncuoğlu from Amasya Darüssifa in the city of Amasya (Fig. 4) [1]. He was justified as a pioneer of pediatric neurosurgery in the fifteenth century Ottoman period.

As a consequence, it is suggested that both Seljuks and Ottomans contributed the formation of science and technology, including medicine and surgery, with their unique educational systems. I would like to suggest that the experiences from these Turkish empires may have some implications to the rapid progress in medicine and surgery in the world in recent years.

\section{References}

1. Uzel I (1992) Cerrahiyyetü'l Haniyye I, 1st edn. Türk Tarih Kurumu Yayınları [Turkish Historical Society], Ankara, pp 155400 (in Turkish)

2. Turgut M (2008) Serefeddin Sabuncuoğlu (1385-1468) on pediatric skull fractures. Historical vignette. Pediatr Neurosurg 44:264-268

3. Shaw S (1976) History of the Ottoman Empire and Modern Turkey, vol. I. Cambridge University Press, USA, pp 115-117

4. Unver SA (1958) The origins of history of Turkish medicine. Institute of History of Medicine, Istanbul University, Istanbul 